\title{
NOTES ON BIPOLAR-VALUED FUZZY SUBGROUPS OF A GROUP M.S.ANITHA ${ }^{1}$, K.L.MURUGANANTHA PRASAD ${ }^{2}$ \& K.ARJUNAN ${ }^{2}$ \\ ${ }^{1}$ Research Scholar, Department of Mathematics,H.H.The Rajahs College, Pudukkottai - 622001 Tamilnadu, India. \\ ${ }^{2}$ Department of Mathematics, H.H.The Rajahs College, Pudukkottai - 622001 \\ Tamilnadu, India .
}

Keywords: Bipolar-valued fuzzy set, bipolar-valued fuzzy subgroup, product, bipolar-valued fuzzy normal subgroup, bipolar-valued fuzzy coset.

Abstract: In this paper, we study some of the properties of bipolar-valued fuzzy subgroup and prove some results on these.

\section{Introduction}

In 1965, Zadeh [12] introduced the notion of a fuzzy subset of a set, fuzzy sets are a kind of useful mathematical structure to represent a collection of objects whose boundary is vague. Since then it has become a vigorous area of research in different domains, there have been a number of generalizations of this fundamental concept such as intuitionistic fuzzy sets, interval- valued fuzzy sets, vague sets, soft sets etc [5]. Lee [7] introduced the notion of bipolar-valued fuzzy sets. Bipolar-valued fuzzy sets are an extension of fuzzy sets whose membership degree range is enlarged from the interval $[0,1]$ to $[-1,1]$. In a bipolar-valued fuzzy set, the membership degree 0 means that elements are irrelevant to the corresponding property, the membership degree $(0,1]$ indicates that elements somewhat satisfy the property and the membership degree $[-1,0)$ indicates that elements somewhat satisfy the implicit counter property. Bipolar-valued fuzzy sets and intuitionistic fuzzy sets look similar each other. However, they are different each other [7, 8]. We introduce the concept of bipolar-valued fuzzy subgroup and established some results.

\section{Preliminaries}

1.1 Definition: A bipolar-valued fuzzy set (BVFS) $\mathrm{A}$ in $\mathrm{X}$ is defined as an object of the form $\mathrm{A}=$ $\left\{<\mathrm{x}, \mathrm{A}^{+}(\mathrm{x}), \mathrm{A}^{-}(\mathrm{x})>/ \mathrm{x} \in \mathrm{X}\right\}$, where $\mathrm{A}^{+}: \mathrm{X} \rightarrow[0,1]$ and $\mathrm{A}^{-}: \mathrm{X} \rightarrow[-1,0]$. The positive membership degree $\mathrm{A}^{+}(\mathrm{x})$ denotes the satisfaction degree of an element $\mathrm{x}$ to the property corresponding to a bipolar-valued fuzzy set $\mathrm{A}$ and the negative membership degree $\mathrm{A}^{-}(\mathrm{x})$ denotes the satisfaction degree of an element $\mathrm{x}$ to some implicit counter-property corresponding to a bipolar-valued fuzzy set $\mathrm{A}$. If $\mathrm{A}^{+}(\mathrm{x}) \neq 0$ and $\mathrm{A}^{-}(\mathrm{x})=0$, it is the situation that $\mathrm{x}$ is regarded as having only positive satisfaction for $\mathrm{A}$ and if $\mathrm{A}^{+}(\mathrm{x})=0$ and $\mathrm{A}^{-}(\mathrm{x}) \neq 0$, it is the situation that $\mathrm{x}$ does not satisfy the property of $\mathrm{A}$, but somewhat satisfies the counter property of $\mathrm{A}$. It is possible for an element $\mathrm{x}$ to be such that $\mathrm{A}^{+}(\mathrm{x}) \neq 0$ and $\mathrm{A}^{-}(\mathrm{x}) \neq 0$ when the membership function of the property overlaps that of its counter property over some portion of $\mathrm{X}$.

1.1 Example: $A=\{<a, 0.5,-0.3>,<b, 0.1,-0.7>,<c, 0.5,-0.4>\}$ is a bipolar-valued fuzzy subset of $X=\{a, b, c\}$.

1.2 Definition: Let $G$ be a group. A bipolar-valued fuzzy subset $A$ of $G$ is said to be a bipolarvalued fuzzy subgroup of G (BVFSG) if the following conditions are satisfied,

$$
\begin{aligned}
& \text { (i) } \mathrm{A}^{+}(\mathrm{xy}) \geq \min \left\{\mathrm{A}^{+}(\mathrm{x}), \mathrm{A}^{+}(\mathrm{y})\right\}, \\
& \text { (ii) } \mathrm{A}^{+}\left(\mathrm{x}^{-1}\right) \geq \mathrm{A}^{+}(\mathrm{x}), \\
& \text { (iii) } \mathrm{A}^{-}(\mathrm{xy}) \leq \max \left\{\mathrm{A}^{-}(\mathrm{x}), \mathrm{A}^{-}(\mathrm{y})\right\},
\end{aligned}
$$


(iv) $\mathrm{A}^{-}\left(\mathrm{x}^{-1}\right) \leq \mathrm{A}^{-}(\mathrm{x})$, for all $\mathrm{x}$ and $\mathrm{y}$ in $\mathrm{G}$.

1.2 Example: Let $G=\{1,-1, i,-i\}$ be a group with respect to the ordinary multiplication. Then $A$ $=\{<1,0.5,-0.6>,<-1,0.4,-0.5>,<\mathrm{i}, 0.2,-0.4>, \quad<-\mathrm{i}, 0.2,-0.4>\}$ is a bipolarvalued fuzzy subgroup of $\mathrm{G}$.

1.3 Definition: Let $\mathrm{A}=\left\langle\mathrm{A}^{+}, \mathrm{A}^{-}\right\rangle$and $\mathrm{B}=\left\langle\mathrm{B}^{+}, \mathrm{B}^{-}\right\rangle$be any two bipolar-valued fuzzy subsets of sets $G$ and $H$, respectively. The product of $A$ and $B$, denoted by $A \times B$, is defined as $A \times B=\{<(x$, $\left.\mathrm{y}),(\mathrm{A} \times \mathrm{B})^{+}(\mathrm{x}, \mathrm{y}),(\mathrm{A} \times \mathrm{B})^{-}(\mathrm{x}, \mathrm{y})\right\rangle /$ for all $\mathrm{x}$ in $\mathrm{G}$ and $\mathrm{y}$ in $\left.\mathrm{H}\right\}$, where $(\mathrm{A} \times \mathrm{B})^{+}(\mathrm{x}, \mathrm{y})=\min \left\{\mathrm{A}^{+}(\mathrm{x})\right.$, $\left.\mathrm{B}^{+}(\mathrm{y})\right\}$ and $(\mathrm{A} \times \mathrm{B})^{-}(\mathrm{x}, \mathrm{y})=\max \left\{\mathrm{A}^{-}(\mathrm{x}), \mathrm{B}^{-}(\mathrm{y})\right\}$, for all $\mathrm{x}$ in $\mathrm{G}$ and $\mathrm{y}$ in $\mathrm{H}$.

1.4 Definition: Let $G$ be a group. A bipolar-valued fuzzy subgroup A of $G$ is said to be a bipolarvalued fuzzy normal subgroup of $\mathrm{G}$ if

(i) $\mathrm{A}^{+}(\mathrm{xy})=\mathrm{A}^{+}(\mathrm{yx})$

(ii) $\quad \mathrm{A}^{-}(\mathrm{xy})=\mathrm{A}^{-}(\mathrm{yx})$, for all $\mathrm{x}$ and $\mathrm{y}$ in $\mathrm{G}$.

1.5 Definition: Let $A$ be a bipolar-valued fuzzy subgroup of a group $G$. For any $a \in G$, aA defined by $\left(\mathrm{aA}^{+}\right)(\mathrm{x})=\mathrm{A}^{+}\left(\mathrm{a}^{-1} \mathrm{x}\right)$ and $\left(\mathrm{aA}^{-}\right)(\mathrm{x})=\mathrm{A}^{-}\left(\mathrm{a}^{-1} \mathrm{x}\right)$, for every $\mathrm{x} \in \mathrm{G}$ is called the bipolar-valued fuzzy coset of the group $\mathrm{G}$.

1.6 Definition: Let $A$ be a bipolar-valued fuzzy subgroup of a group $G$ and $H=\left\{x \in G / A^{+}(x)\right.$ $=\mathrm{A}^{+}(\mathrm{e})$ and $\left.\mathrm{A}^{-}(\mathrm{x})=\mathrm{A}^{-}(\mathrm{e})\right\}$, then $\mathrm{o}(\mathrm{A})$, order of $\mathrm{A}$ is defined as $\mathrm{o}(\mathrm{A})=\mathrm{o}(\mathrm{H})$.

1.7 Definition: Let A and B be two bipolar-valued fuzzy subgroups of a group $G$. Then A and B are said to be conjugate bipolar-valued fuzzy subgroup of $G$ if for some $g \in G, A^{+}(x)=B^{+}\left(g^{-1} x g\right)$ and $\mathrm{A}^{-}(\mathrm{x})=\mathrm{B}^{-}\left(\mathrm{g}^{-1} \mathrm{xg}\right)$, for every $\mathrm{x} \in \mathrm{G}$.

1.8 Definition: Let A be a bipolar-valued fuzzy subgroup of a group $G$. Then for any a and $b$ in $G$, a bipolar-valued fuzzy middle coset $a A b$ of $G$ is defined by $\left(a^{+} b\right)(x)=A^{+}\left(a^{-1} x^{-1}\right)$ and $\left(a A^{-} b\right)(x)$ $=\mathrm{A}^{-}\left(\mathrm{a}^{-1} \mathrm{x} \mathrm{b}^{-1}\right)$, for every $\mathrm{x} \in \mathrm{G}$.

\section{PROPERTIES:}

2.1 Theorem: Let $\mathrm{A}=\left\langle\mathrm{A}^{+}, \mathrm{A}^{-}\right\rangle$be a bipolar-valued fuzzy subgroup of a group $\mathrm{G}$. If $\mathrm{A}^{+}(\mathrm{x})<$ $\mathrm{A}^{+}(\mathrm{y})$ and $\mathrm{A}^{-}(\mathrm{x})>\mathrm{A}^{-}(\mathrm{y})$, for some $\mathrm{x}$ and $\mathrm{y}$ in $\mathrm{G}$, then

(i) $\quad \mathrm{A}^{+}(\mathrm{xy})=\mathrm{A}^{+}(\mathrm{x})=\mathrm{A}^{+}(\mathrm{yx})$ and (ii) $\mathrm{A}^{-}(\mathrm{xy})=\mathrm{A}^{-}(\mathrm{x})=\mathrm{A}^{-}(\mathrm{yx})$

proof: Let $A=\left\langle A^{+}, A^{-}\right\rangle$be a bipolar-valued fuzzy subgroup of a group $G$.

Let $\mathrm{A}^{+}(\mathrm{x})<\mathrm{A}^{+}(\mathrm{y})$ and $\mathrm{A}^{-}(\mathrm{x})>\mathrm{A}^{-}(\mathrm{y})$, for some $\mathrm{x}$ and $\mathrm{y}$ in $\mathrm{G}$.

Now, $\mathrm{A}^{+}(\mathrm{xy}) \geq \min \left\{\mathrm{A}^{+}(\mathrm{x}), \mathrm{A}^{+}(\mathrm{y})\right\}=\mathrm{A}^{+}(\mathrm{x})$; and

$\mathrm{A}^{+}(\mathrm{x})=\mathrm{A}^{+}\left(\mathrm{xyy}^{-1}\right) \geq \min \left\{\mathrm{A}^{+}(\mathrm{xy}), \mathrm{A}^{+}(\mathrm{y})\right\}=\mathrm{A}^{+}(\mathrm{xy})$.

Also, $\mathrm{A}^{+}(\mathrm{yx}) \geq \min \left\{\mathrm{A}^{+}(\mathrm{y}), \mathrm{A}^{+}(\mathrm{x})\right\}=\mathrm{A}^{+}(\mathrm{x})$; and

$\mathrm{A}^{+}(\mathrm{x})=\mathrm{A}^{+}\left(\mathrm{y}^{-1} \mathrm{yx}\right) \geq \min \left\{\mathrm{A}^{+}(\mathrm{y}), \mathrm{A}^{+}(\mathrm{yx})\right\}=\mathrm{A}^{+}(\mathrm{yx})$.

Therefore $A^{+}(x y)=A^{+}(x)=A^{+}(y x)$. Hence (i) is proved.

Now, $\mathrm{A}^{-}(\mathrm{xy}) \leq \max \left\{\mathrm{A}^{-}(\mathrm{x}), \mathrm{A}^{-}(\mathrm{y})\right\}=\mathrm{A}^{-}(\mathrm{x})$; and

$\mathrm{A}^{-}(\mathrm{x})=\mathrm{A}^{-}\left(\mathrm{xyy}^{-1}\right) \leq \max \left\{\mathrm{A}^{-}(\mathrm{xy}), \mathrm{A}^{-}(\mathrm{y})\right\}=\mathrm{A}^{-}(\mathrm{xy})$.

Also, $\mathrm{A}^{-}(\mathrm{yx}) \leq \max \left\{\mathrm{A}^{-}(\mathrm{y}), \mathrm{A}^{-}(\mathrm{x})\right\}=\mathrm{A}^{-}(\mathrm{x})$; and

$\mathrm{A}^{-}(\mathrm{x})=\mathrm{A}^{-}\left(\mathrm{y}^{-1} \mathrm{yx}\right) \leq \max \left\{\mathrm{A}^{-}(\mathrm{y}), \mathrm{A}^{-}(\mathrm{yx})\right\}=\mathrm{A}^{-}(\mathrm{yx})$.

Therefore $\mathrm{A}^{-}(\mathrm{xy})=\mathrm{A}^{-}(\mathrm{x})=\mathrm{A}^{-}(\mathrm{yx})$. Hence (ii) is proved. 
2.2 Theorem: Let $A=\left\langle A^{+}, A^{-}\right\rangle$be a bipolar-valued fuzzy subgroup of a group $G$. If $A^{+}(x)<A^{+}(y)$ and $\mathrm{A}^{-}(\mathrm{x})<\mathrm{A}^{-}(\mathrm{y})$, for some $\mathrm{x}$ and $\mathrm{y}$ in $\mathrm{G}$, then

(i) $\quad \mathrm{A}^{+}(\mathrm{xy})=\mathrm{A}^{+}(\mathrm{x})=\mathrm{A}^{+}(\mathrm{yx})$ and (ii) $\mathrm{A}^{-}(\mathrm{xy})=\mathrm{A}^{-}(\mathrm{y})=\mathrm{A}^{-}(\mathrm{yx})$

proof: Let $A=\left\langle A^{+}, A^{-}\right\rangle$be a bipolar-valued fuzzy subgroup of a group $G$.

Let $\mathrm{A}^{+}(\mathrm{x})<\mathrm{A}^{+}(\mathrm{y})$ and $\mathrm{A}^{-}(\mathrm{x})<\mathrm{A}^{-}(\mathrm{y})$, for some $\mathrm{x}$ and $\mathrm{y}$ in $\mathrm{G}$.

Now, $\mathrm{A}^{+}(\mathrm{xy}) \geq \min \left\{\mathrm{A}^{+}(\mathrm{x}), \mathrm{A}^{+}(\mathrm{y})\right\}=\mathrm{A}^{+}(\mathrm{x})$; and

$\mathrm{A}^{+}(\mathrm{x})=\mathrm{A}^{+}\left(\mathrm{xyy}^{-1}\right) \geq \min \left\{\mathrm{A}^{+}(\mathrm{xy}), \mathrm{A}^{+}(\mathrm{y})\right\}=\mathrm{A}^{+}(\mathrm{xy})$.

And, $\mathrm{A}^{+}(\mathrm{yx}) \geq \min \left\{\mathrm{A}^{+}(\mathrm{y}), \mathrm{A}^{+}(\mathrm{x})\right\}=\mathrm{A}^{+}(\mathrm{x})$; and

$\mathrm{A}^{+}(\mathrm{x})=\mathrm{A}^{+}\left(\mathrm{y}^{-1} \mathrm{yx}\right) \geq \min \left\{\mathrm{A}^{+}(\mathrm{y}), \mathrm{A}^{+}(\mathrm{yx})\right\}=\mathrm{A}^{+}(\mathrm{yx})$.

Therefore $A^{+}(x y)=A^{+}(x)=A^{+}(y x)$. Hence (i) is proved .

Now, $\mathrm{A}^{-}(\mathrm{xy}) \leq \max \left\{\mathrm{A}^{-}(\mathrm{x}), \mathrm{A}^{-}(\mathrm{y})\right\}=\mathrm{A}^{-}(\mathrm{y})$; and

$\mathrm{A}^{-}(\mathrm{y})=\mathrm{A}^{-}\left(\mathrm{x}^{-1} \mathrm{xy}\right) \leq \max \left\{\mathrm{A}^{-}(\mathrm{x}), \mathrm{A}^{-}(\mathrm{xy})\right\}=\mathrm{A}^{-}(\mathrm{xy})$.

And, $\mathrm{A}^{-}(\mathrm{yx}) \leq \max \left\{\mathrm{A}^{-}(\mathrm{y}), \mathrm{A}^{-}(\mathrm{x})\right\}=\mathrm{A}^{-}(\mathrm{y})$; and

$\mathrm{A}^{-}(\mathrm{y})=\mathrm{A}^{-}\left(\mathrm{yxx}^{-1}\right) \leq \max \left\{\mathrm{A}^{-}(\mathrm{yx}), \mathrm{A}^{-}(\mathrm{x})\right\}=\mathrm{A}^{-}(\mathrm{yx})$.

Therefore $\mathrm{A}^{-}(\mathrm{xy})=\mathrm{A}^{-}(\mathrm{y})=\mathrm{A}^{-}(\mathrm{yx})$. Hence (ii) is proved.

2.3 Theorem: Let $\mathrm{A}=\left\langle\mathrm{A}^{+}, \mathrm{A}^{-}\right\rangle$be a bipolar-valued fuzzy subgroup of a group $\mathrm{G}$. If

$\mathrm{A}^{+}(\mathrm{x})>\mathrm{A}^{+}(\mathrm{y})$ and $\mathrm{A}^{-}(\mathrm{x})>\mathrm{A}^{-}(\mathrm{y})$, for some $\mathrm{x}$ and $\mathrm{y}$ in $\mathrm{G}$, then

(i) $\quad \mathrm{A}^{+}(\mathrm{xy})=\mathrm{A}^{+}(\mathrm{y})=\mathrm{A}^{+}(\mathrm{yx})$ and (ii) $\mathrm{A}^{-}(\mathrm{xy})=\mathrm{A}^{-}(\mathrm{x})=\mathrm{A}^{-}(\mathrm{yx})$. Proof: It is trivial.

2.4 Theorem: Let $A=\left\langle A^{+}, A^{-}\right\rangle$be a bipolar-valued fuzzy subgroup of a group $G$. If $\left.A^{+}(x)\right\rangle$ $\mathrm{A}^{+}(\mathrm{y})$ and $\mathrm{A}^{-}(\mathrm{x})<\mathrm{A}^{-}(\mathrm{y})$, for some $\mathrm{x}$ and $\mathrm{y}$ in $\mathrm{G}$, then

(i) $\mathrm{A}^{+}(\mathrm{xy})=\mathrm{A}^{+}(\mathrm{y})=\mathrm{A}^{+}(\mathrm{yx})$ and (ii) $\mathrm{A}^{-}(\mathrm{xy})=\mathrm{A}^{-}(\mathrm{y})=\mathrm{A}^{-}(\mathrm{yx})$.

Proof: It is trivial.

2.5 Theorem: Let $\mathrm{A}=\left\langle\mathrm{A}^{+}, \mathrm{A}^{-}\right\rangle$be a bipolar-valued fuzzy subgroup of a finite group $\mathrm{G}$, then $\mathrm{o}(\mathrm{A})$ divides $\mathrm{o}(\mathrm{G})$.

Proof: Let A be a bipolar-valued fuzzy subgroup of a finite group $\mathrm{G}$ with e as its identity element. Clearly $\mathrm{H}=\left\{\mathrm{x} \in \mathrm{G} / \mathrm{A}^{+}(\mathrm{x})=\mathrm{A}^{+}(\mathrm{e})\right.$ and $\left.\mathrm{A}^{-}(\mathrm{x})=\mathrm{A}^{-}(\mathrm{e})\right\}$ is a subgroup of the group $\mathrm{G}$. By Lagranges theorem $\mathrm{o}(\mathrm{H}) \mid \mathrm{o}(\mathrm{G})$.

Hence by the definition of the order of the bipolar-valued fuzzy subgroup of the group $G$, we have o(A) $\mid \mathrm{o}(\mathrm{G})$.

2.6 Theorem: Let $A=\left\langle A^{+}, A^{-}\right\rangle$and $B=\left\langle B^{+}, B^{-}\right\rangle$be two bipolar-valued fuzzy subsets of a abelian group $\mathrm{G}$. Then $\mathrm{A}$ and $\mathrm{B}$ are conjugate bipolar-valued fuzzy subsets of the group $\mathrm{G}$ if and only if $\mathrm{A}=\mathrm{B}$.

Proof: Let $A$ and $B$ be conjugate bipolar-valued fuzzy subsets of group $G$, then for some $y \in G$, we have $\mathrm{A}^{+}(\mathrm{x})=\mathrm{B}^{+}\left(\mathrm{y}^{-1} \mathrm{xy}\right)=\mathrm{B}^{+}\left(\mathrm{y}^{-1} \mathrm{yx}\right)=\mathrm{B}^{+}(\mathrm{ex})=\mathrm{B}^{+}(\mathrm{x})$.

Therefore $\mathrm{A}^{+}(\mathrm{x})=\mathrm{B}^{+}(\mathrm{x})$.

And, $\mathrm{A}^{-}(\mathrm{x})=\mathrm{B}^{-}\left(\mathrm{y}^{-1} \mathrm{xy}\right)=\mathrm{B}^{-}\left(\mathrm{y}^{-1} \mathrm{yx}\right)=\mathrm{B}^{-}(\mathrm{ex})=\mathrm{B}^{-}(\mathrm{x})$.

Therefore $\mathrm{A}^{-}(\mathrm{x})=\mathrm{B}^{-}(\mathrm{x})$. Hence $\mathrm{A}=\mathrm{B}$.

Conversely if $A=B$ then for the identity element e of group $G$, we have $\mathrm{A}^{+}(\mathrm{x})=\mathrm{B}^{+}\left(\mathrm{e}^{-1} \mathrm{xe}\right)$ and $\mathrm{A}^{-}(\mathrm{x})=\mathrm{B}^{-}\left(\mathrm{e}^{-1} \mathrm{xe}\right)$ for every $\mathrm{x} \in \mathrm{G}$.

Hence $\mathrm{A}$ and $\mathrm{B}$ are conjugate bipolar-valued fuzzy subsets of the group $\mathrm{G}$. 
2.7 Theorem: If $A=\left\langle A^{+}, A^{-}\right\rangle$and $B=\left\langle B^{+}, B^{-}\right\rangle$are conjugate bipolar-valued fuzzy subgroups of the group $\mathrm{G}$, then $\mathrm{o}(\mathrm{A})=\mathrm{o}(\mathrm{B})$.

Proof: Let $A$ and $B$ are conjugate bipolar-valued fuzzy subgroups of the group $\mathrm{G}$.

Now, o $(A)=$ order of $\left\{x \in G / A^{+}(x)=A^{+}(e)\right.$ and $\left.A^{-}(x)=A^{-}(e)\right\}$

$$
\begin{aligned}
& =\operatorname{order} \text { of }\left\{x \in G / B^{+}\left(y^{-1} x y\right)=B^{+}\left(y^{-1} e y\right) \text { and } B^{-}\left(y^{-1} x y\right)=B^{-}\left(y^{-1} e y\right)\right\} \\
& =\text { order of }\left\{x \in G / B^{+}(x)=B^{+}(e) \text { and } B^{-}(x)=B^{-}(e)\right\} \\
& =o(B) \text { Hence } o(A)=o(B) \text {. }
\end{aligned}
$$

2.8 Theorem: Let $A=\left\langle A^{+}, A^{-}\right\rangle$be a bipolar-valued fuzzy normal subgroup of a group $G$. Then for any $y$ in $G$ we have $A^{+}\left(y x y^{-1}\right)=A^{+}\left(y^{-1} x y\right)$ and $A^{-}\left(y x y^{-1}\right)=A^{-}\left(y^{-1} x y\right)$, for every $x \in G$.

Proof: Let A be a bipolar-valued fuzzy normal subgroup of a group G.

For any $\mathrm{y}$ in $\mathrm{G}$. Then we have, $\mathrm{A}^{+}\left(\mathrm{yxy}^{-1}\right)=\mathrm{A}^{+}(\mathrm{x})=\mathrm{A}^{+}\left(\mathrm{xyy}^{-1}\right)=\mathrm{A}^{+}\left(\mathrm{y}^{-1} \mathrm{xy}\right)$.

Therefore $\mathrm{A}^{+}\left(\mathrm{yxy}^{-1}\right)=\mathrm{A}^{+}\left(\mathrm{y}^{-1} \mathrm{xy}\right)$.

And, $A^{-}\left(\mathrm{yxy}^{-1}\right)=\mathrm{A}^{-}(\mathrm{x})=\mathrm{A}^{-}\left(\mathrm{xyy}^{-1}\right)=\mathrm{A}^{-}\left(\mathrm{y}^{-1} \mathrm{xy}\right)$.

Therefore $A^{-}\left(y_{x y}^{-1}\right)=A^{-}\left(y^{-1} x y\right)$.

2.9 Theorem: A bipolar-valued fuzzy subgroup $A=\left\langle A^{+}, A^{-}\right\rangle$of a group $G$ is normalized if and only if $\mathrm{A}^{+}(\mathrm{e})=1$ and $\mathrm{A}^{-}(\mathrm{e})=0$, where $\mathrm{e}$ is the identity element of the group $\mathrm{G}$.

Proof: If $A$ is normalized then there exists $x \in G$ such that $A^{+}(x)=1$ and $A^{-}(x)=0$, but by properties of a bipolar-valued fuzzy subgroup $A$ of the group $G, A^{+}(x) \leq A^{+}(e)$ and $A^{-}(x) \geq$ $\mathrm{A}^{-}(\mathrm{e})$ for every $\mathrm{x} \in \mathrm{G}$.

since $\mathrm{A}^{+}(\mathrm{x})=1$ and $\mathrm{A}^{-}(\mathrm{x})=0$ and $\mathrm{A}^{+}(\mathrm{x}) \leq \mathrm{A}^{+}(\mathrm{e})$ and $\mathrm{A}^{-}(\mathrm{x}) \geq \mathrm{A}^{-}(\mathrm{e})$.

Therefore $1 \leq \mathrm{A}^{+}(\mathrm{e})$ and $0 \geq \mathrm{A}^{-}(\mathrm{e})$. But $1 \geq \mathrm{A}^{+}(\mathrm{e})$ and $0 \leq \mathrm{A}^{-}(\mathrm{e})$.

Hence $\mathrm{A}^{+}(\mathrm{e})=1$ and $\mathrm{A}^{-}(\mathrm{e})=0$.

Conversely if $\mathrm{A}^{+}(\mathrm{e})=1$ and $\mathrm{A}^{-}(\mathrm{e})=0$, then by the definition of normalized bipolar-valued fuzzy subset A is normalized.

2.10 Theorem: If $A=\left\langle A^{+}, A^{-}\right\rangle$is a bipolar-valued fuzzy subgroup of a group $G$, then for any a in $\mathrm{G}$ the bipolar-valued fuzzy middle coset $\mathrm{aAa}^{-1}$ of $\mathrm{G}$ is also a bipolar-valued fuzzy subgroup of a group G.

Proof: Let $A$ is a bipolar-valued fuzzy subgroup of a group $\mathrm{G}$ and $\mathrm{a}$ in $\mathrm{G}$. To prove $\quad \mathrm{aAa}^{-1}=$ $\left(\mathrm{x}, \mathrm{aA}^{+} \mathrm{a}^{-1}, \mathrm{aA}^{-} \mathrm{a}^{-1}\right)$ is a bipolar-valued fuzzy subgroup of $\mathrm{G}$. Let $\mathrm{x}$ and $\mathrm{y}$ in $\mathrm{G}$.

Then $\left(a A^{+} a^{-1}\right)\left(x y^{-1}\right)=A^{+}\left(a^{-1} x y^{-1} a\right)$

$$
\begin{aligned}
& =A^{+}\left(a^{-1} x a a^{-1} y^{-1} a\right) \\
& =A^{+}\left(a^{-1} x a\left(a^{-1} y a\right)^{-1}\right) \\
& \geq \min \left\{A^{+}\left(a^{-1} x a\right), A^{+}\left(a^{-1} y a\right)\right\} \\
& =\min \left\{\left(a A^{+} a^{-1}\right)(x),\left(a A^{+} a^{-1}\right)(y)\right\} .
\end{aligned}
$$

Therefore $\left(\mathrm{a} \mathrm{A}^{+} \mathrm{a}^{-1}\right)\left(x y^{-1}\right) \geq \min \left\{\left(\mathrm{a} \mathrm{A}^{+} \mathrm{a}^{-1}\right)(\mathrm{x}),\left(\mathrm{a} \mathrm{A}^{+} \mathrm{a}^{-1}\right)(\mathrm{y})\right\}$.

And $\left(\mathrm{a} \mathrm{A}^{-} \mathrm{a}^{-1}\right)\left(x \mathrm{y}^{-1}\right)=\mathrm{A}^{-}\left(\mathrm{a}^{-1} \mathrm{xy}^{-1} \mathrm{a}\right)$

$$
=A^{-}\left(a^{-1} x^{-1} y^{-1} a\right)
$$




$$
\begin{aligned}
& =\mathrm{A}^{-}\left(\mathrm{a}^{-1} \mathrm{xa}\left(\mathrm{a}^{-1} \mathrm{ya}\right)^{-1}\right) \\
& \leq \max \left\{\mathrm{A}^{-}\left(\mathrm{a}^{-1} \mathrm{xa}\right), \mathrm{A}^{-}\left(\mathrm{a}^{-1} \mathrm{ya}\right)\right\} \\
& =\max \left\{\left(\mathrm{a} \mathrm{A}^{-} \mathrm{a}^{-1}\right)(\mathrm{x}),\left(\mathrm{a} \mathrm{A}^{-} \mathrm{a}^{-1}\right)(\mathrm{y})\right\} .
\end{aligned}
$$

Therefore $\left(\mathrm{a} \mathrm{A}^{-} \mathrm{a}^{-1}\right)\left(x y^{-1}\right) \leq \max \left\{\left(\mathrm{a} \mathrm{A}^{-} \mathrm{a}^{-1}\right)(\mathrm{x}),\left(\mathrm{a} \mathrm{A}^{-} \mathrm{a}^{-1}\right)(\mathrm{y})\right\}$. Hence $a \mathrm{Aa}^{-1}$ is a bipolar-valued fuzzy subgroup of a group $\mathrm{G}$.

2.11 Theorem: Let $A=\left\langle A^{+}, A^{-}\right\rangle$be a bipolar-valued fuzzy subgroup of a group $G$ and $a A^{-1}$ be a bipolar-valued fuzzy middle coset of the group $G$, then $o\left(\mathrm{aAa}^{-1}\right)=\mathrm{o}(\mathrm{A})$, for any $\mathrm{a} \in \mathrm{G}$.

Proof: Let $A$ be a bipolar-valued fuzzy subgroup of a group $G$ and $a \in G$. By Theorem 2.10, the bipolar-valued fuzzy middle coset $\mathrm{aAa}^{-1}$ is a bipolar-valued fuzzy subgroup of a group $\mathrm{G}$. Further by the definition of a bipolar-valued fuzzy middle coset of the group $G$ we have $\left(\mathrm{a} \mathrm{A}^{+} \mathrm{a}^{-1}\right)(\mathrm{x})$ $=\mathrm{A}^{+}\left(\mathrm{a}^{-1} \mathrm{xa}\right)$ and $\left(\mathrm{a} \mathrm{A}^{-} \mathrm{a}^{-1}\right)(\mathrm{x})=\mathrm{A}^{-}\left(\mathrm{a}^{-1} \mathrm{xa}\right)$, for every $\mathrm{x}$ in $\mathrm{G}$.

Hence for any a in $\mathrm{G}, \mathrm{A}$ and $\mathrm{aAa}^{-1}$ are conjugate bipolar-valued fuzzy subgroup of the group $\mathrm{G}$ as there exists $a \in G$ such that $\left(a A^{+} a^{-1}\right)(x)=A^{+}\left(a^{-1} x a\right)$ and $\left(a A^{-} a^{-1}\right)(x)=A^{-}\left(a^{-1} x a\right)$ for every $x$ in $G$. By Theorem 2.6, $\mathrm{o}\left(\mathrm{aAa}^{-1}\right)=\mathrm{o}(\mathrm{A})$ for any $\mathrm{a}$ in $\mathrm{G}$.

2.12 Theorem: Let $A=\left\langle A^{+}, A^{-}\right\rangle$be a bipolar-valued fuzzy subgroup of a group $G$ and $B=\left\langle B^{+}, B^{-}\right\rangle$ be a bipolar-valued fuzzy subset of a group $\mathrm{G}$. If $\mathrm{A}$ and $\mathrm{B}$ are conjugate bipolar-valued fuzzy subsets of the group $\mathrm{G}$ then $\mathrm{B}$ is a bipolar-valued fuzzy subgroup of a group $\mathrm{G}$.

Proof: Let A be a bipolar-valued fuzzy subgroup of a group $G$ and B be a bipolar-valued fuzzy subset of a group G. And let A and B are conjugate bipolar-valued fuzzy subsets of the group $\mathrm{G}$. To prove $\mathrm{B}$ is a bipolar-valued fuzzy subgroup of the group $\mathrm{G}$.

Let $\mathrm{x}$ and $\mathrm{y}$ in $\mathrm{G}$. Then $x \mathrm{y}^{-1}$ in $\mathrm{G}$.

Now, $B^{+}\left(x y^{-1}\right)=A^{+}\left(g^{-1} x y^{-1} g\right)=A^{+}\left(g^{-1} x g g^{-1} y^{-1} g\right)=A^{+}\left(g^{-1} x g\left(g^{-1} y g\right)^{-1}\right) \geq \min \left\{A^{+}\left(g^{-1} x g\right)\right.$, $\left.\mathrm{A}^{+}\left(\mathrm{g}^{-1} \mathrm{yg}\right)\right\}=\min \left\{\mathrm{B}^{+}(\mathrm{x}), \mathrm{B}^{+}(\mathrm{y})\right\}$. Therefore $\mathrm{B}^{+}\left(\mathrm{xy}^{-1}\right) \geq \min \left\{\mathrm{B}^{+}(\mathrm{x}), \mathrm{B}^{+}(\mathrm{y})\right\}$.

And $B^{-}\left(x^{-1}\right)=A^{-}\left(g^{-1} x y^{-1} g\right)=A^{-}\left(g^{-1} x g g^{-1} y^{-1} g\right)=A^{-}\left(g^{-1} x g\left(g^{-1} y g\right)^{-1}\right) \leq \max \left\{A^{-}\left(g^{-1} x g\right), A^{-}\left(g^{-1} y g\right)\right.$ \}$=\max \left\{\mathrm{B}^{-}(\mathrm{x}), \mathrm{B}^{-}(\mathrm{y})\right\}$.

Therefore $\mathrm{B}^{-}\left(\mathrm{xy}^{-1}\right) \leq \max \left\{\mathrm{B}^{-}(\mathrm{x}), \mathrm{B}^{-}(\mathrm{y})\right\}$. Hence $\mathrm{B}$ is a bipolar-valued fuzzy subgroup of the group G.

2.13 Theorem: Let a bipolar-valued fuzzy subgroup $A=\left\langle A^{+}, A^{-}\right\rangle$of a group $G$ be conjugate to a bipolar-valued fuzzy subgroup $\mathrm{M}=\left\langle\mathrm{M}^{+}, \mathrm{M}^{-}\right\rangle$of $\mathrm{G}$ and a bipolar-valued fuzzy subgroup $\mathrm{B}=\left\langle\mathrm{B}^{+}\right.$, $\left.B^{-}\right\rangle$of a group $H$ be conjugate to a bipolar-valued fuzzy subgroup $N=\left\langle N^{+}, N^{-}\right\rangle$of $H$. Then a bipolar-valued fuzzy subgroup $\mathrm{A} \times \mathrm{B}=\left\langle(\mathrm{A} \times \mathrm{B})^{+},(\mathrm{A} \times \mathrm{B})^{-}\right\rangle$of a group $\mathrm{G} \times \mathrm{H}$ is conjugate to a bipolar-valued fuzzy subgroup $\mathrm{M} \times \mathrm{N}=\left\langle(\mathrm{M} \times \mathrm{N})^{+},(\mathrm{M} \times \mathrm{N})^{-}\right\rangle$of $\mathrm{G} \times \mathrm{H}$.

Proof: Let A and B be bipolar-valued fuzzy subgroups of the groups $\mathrm{G}$ and $\mathrm{H}$. Let $\mathrm{x}, \mathrm{x}^{-1}$ and $\mathrm{f}$ be in $\mathrm{G}$ and $\mathrm{y}, \mathrm{y}^{-1}$ and $\mathrm{g}$ be in $\mathrm{H}$. Then $(\mathrm{x}, \mathrm{y}),\left(\mathrm{x}^{-1}, \mathrm{y}^{-1}\right)$ and $(\mathrm{f}, \mathrm{g})$ are in $\mathrm{G} \times \mathrm{H}$.

Now, $(\mathrm{A} \times \mathrm{B})^{+}(\mathrm{f}, \mathrm{g})=\min \left\{\mathrm{A}^{+}(\mathrm{f}), \mathrm{B}^{+}(\mathrm{g})\right\}=\min \left\{\mathrm{M}^{+}\left(\mathrm{xf} \mathrm{x}^{-1}\right), \mathrm{N}^{+}\left(\mathrm{yg} \mathrm{y}^{-1}\right)\right\}$

$$
\begin{aligned}
& =(\mathrm{M} \times \mathrm{N})^{+}\left(\mathrm{xfx}^{-1}, \mathrm{ygy}^{-1}\right)=(\mathrm{M} \times \mathrm{N})^{+}\left[(\mathrm{x}, \mathrm{y})(\mathrm{f}, \mathrm{g})\left(\mathrm{x}^{-1}, \mathrm{y}^{-1}\right)\right] \\
& =(\mathrm{M} \times \mathrm{N})^{+}\left[(\mathrm{x}, \mathrm{y})(\mathrm{f}, \mathrm{g})(\mathrm{x}, \mathrm{y})^{-1}\right] .
\end{aligned}
$$

Therefore, $(\mathrm{A} \times \mathrm{B})^{+}(\mathrm{f}, \mathrm{g})=(\mathrm{M} \times \mathrm{N})^{+}\left[(\mathrm{x}, \mathrm{y})(\mathrm{f}, \mathrm{g})(\mathrm{x}, \mathrm{y})^{-1}\right]$.

And, $(\mathrm{A} \times \mathrm{B})^{-}(\mathrm{f}, \mathrm{g})=\max \left\{\mathrm{A}^{-}(\mathrm{f}), \mathrm{B}^{-}(\mathrm{g})\right\}=\max \left\{\mathrm{M}^{-}\left(\mathrm{xf} \mathrm{x}^{-1}\right), \mathrm{N}^{-}\left(\mathrm{yg} \mathrm{y}^{-1}\right)\right\}$

$$
\begin{aligned}
& =(\mathrm{M} \times \mathrm{N})^{-}\left(\mathrm{xf} \mathrm{x}^{-1}, \mathrm{yg} \mathrm{y}^{-1}\right)=(\mathrm{M} \times \mathrm{N})^{-}\left[(\mathrm{x}, \mathrm{y})(\mathrm{f}, \mathrm{g})\left(\mathrm{x}^{-1}, \mathrm{y}^{-1}\right)\right] \\
& =(\mathrm{M} \times \mathrm{N})^{-}\left[(\mathrm{x}, \mathrm{y})(\mathrm{f}, \mathrm{g})(\mathrm{x}, \mathrm{y})^{-1}\right] .
\end{aligned}
$$


Therefore, $(A \times B)^{-}(f, g)=(M \times N)^{-}\left[(x, y)(f, g)(x, y)^{-1}\right]$.

Hence a bipolar-valued fuzzy subgroup $\mathrm{A} \times \mathrm{B}$ of a group $\mathrm{G} \times \mathrm{H}$ is conjugate to a bipolar-valued fuzzy subgroup $\mathrm{M} \times \mathrm{N}$ of $\mathrm{G} \times \mathrm{H}$.

\section{References}

[1] Anthony.J.M. and Sherwood.H, Fuzzy groups Redefined, Journal of mathematical analysis and applications, 69,124 -130 (1979).

[2] Arsham Borumand Saeid, bipolar-valued fuzzy BCK/BCI-algebras, World Applied Sciences Journal 7 (11): 1404-1411(2009).

[3] Azriel Rosenfeld, Fuzzy groups, Journal of mathematical analysis and applications 35, 512517 (1971).

[4] Choudhury.F.P. and Chakraborty.A.B. and Khare.S.S., A note on fuzzy subgroups and fuzzy homomorphism, Journal of mathematical analysis and applications, 131, 537 -553 (1988).

[5] Gau, W.L. and D.J. Buehrer, Vague sets, IEEE Transactons on Systems, Man and Cybernetics, 23: 610-614(1993).

[6] Kyoung Ja Lee, bipolar fuzzy subalgebras and bipolar fuzzy ideals of BCK/BCI-algebras, Bull. Malays.Math. Sci. Soc. (2) 32(3), 361-373 (2009).

[7] Lee, K.M., Bipolar-valued fuzzy sets and their operations. Proc. Int. Conf. on Intelligent Technologies, Bangkok, Thailand, pp: 307-312(2000).

[8] Lee, K.M., Comparison of interval-valued fuzzy sets, intuitionistic fuzzy sets and bipolarvalued fuzzy sets. J. Fuzzy Logic Intelligent Systems, 14 (2): 125-129(2004).

[9] Mustafa Akgul, some properties of fuzzy groups, Journal of mathematical analysis and applications, 133, $93-100$ (1988).

[10] Samit Kumar Majumder, Bipolar Valued Fuzzy Sets in $\Gamma$-Semigroups, Mathematica Aeterna, Vol. 2, no. 3, 203 - 213(2012).

[11] Young Bae Jun and Seok Zun Song, Subalgebras and closed ideals of BCH-algebras based on bipolar-valued fuzzy sets, Scientiae Mathematicae Japonicae Online, 427-437 (2008).

[12] Zadeh, L.A., Fuzzy sets, Inform. And Control, 8: 338-353(1965). 